\title{
Plasma-I nduced Changes in the Physiology of Mammalian Retinal Glial Cells: Role of Glutamate
}

SHUNJ I KUSAKA, ${ }^{1}$ NATALIA V. KAPOUSTA-BRUNEAU, ${ }^{1}$ AND DONALD G. PURO1,2*

${ }^{1}$ Department of Ophthal mology, University of Michigan, Ann Arbor, Michigan

2Department of Physiology, University of Michigan, Ann Arbor, Michigan

\begin{abstract}
KEY WORDS blood-retinal barrier; electroretinogram; GLAST; glutamate; Müller
\end{abstract} cell; potassium channels

\begin{abstract}
Plasma can leak into the nervous system when the vascular endothelial barrier is compromised. Although this occurs commonly, little is known about the effects of plasma on the function of cells in the central nervous system. In this study, we focused on the responses of glial cells, which, because they ensheathe the blood vessels, are the first cells exposed to leaking plasma. We used the perforated-patch configuration of the patch-clamp technique to assess the effects of plasma on freshly dissociated bovine and human Müller cells, the principal glia of the retina. To monitor the function of Müller cells in situ, we recorded electroretinograms from isolated retinas. We found that plasma activates an electrogenic glutamate transporter and inhibits inward-rectifying $\mathrm{K}^{+}$ channels, as well as a transient outward current. Glutamate, a normal constituent of the blood, mimicked these effects. Unlike our recent findings with serum, which contains molecules generated by the clotting process, plasma neither activated a nonspecific cation conductance nor inhibited the sl ow $\mathrm{P}_{\text {III }}$ component of the el ectroretinogram, which is generated by Müller cells responding to light-evoked changes in the extracellular potassium concentration $\left(\left[\mathrm{K}^{+}\right]_{0}\right)$. Taken together, our observations indicate that a leakage of serum into the retina compromises the regulation of $\left[\mathrm{K}^{+}\right]_{\circ}$ by Müller cells; however, when plasma enters the retina at sites of a breakdown in the blood-retinal barrier, these glia can maintain $\mathrm{K}^{+}$homeostasis while reducing the potentially neurotoxic levels of glutamate. GLIA 25:205-215, 1999.
\end{abstract}

\section{INTRODUCTION}

A breakdown of the barrier between the circulatory and nervous systems is a frequently occurring pathophysiological event. Compromise of this barrier results in a leakage of plasma or, if there is hemorrhage and clotting, of serum. Although the function of the central nervous system can be impaired by a leakage of molecules and fluid from blood vessels, our knowledge of the effects of plasma or serum on cells of the nervous system is limited. To learn more about the response of the central nervous system, we focused on glial cells that envelope the blood vessels and, consequently, are the first cells exposed to molecules leaking from the vascular system. We hypothesized that the response of the glia to blood-derived molecules plays an important role in determining whether neural circuits maintain function or become dysfunctional when the vascular endothelial barrier is defective.

Recently, we (Kusaka et al., 1998) found that exposure to serum alters the activity of several types of ion channels in Müller cells, the predominant glia of the retina. Associated with these serum-induced changes, there was a decrease in the sl ow $\mathrm{P}_{|| l}$ component of the

Abbreviations: ERG, el ectroretinogram; GLAST, L-glutamate/L-aspartatetransporter; I-V, current-voltage; $K_{A}$, transient outward potassium; $K_{I R}$, inwardly rectifying potassium; $\left[\mathrm{K}^{+}\right]_{0}$, extracellular potassium concentration; $\left[\mathrm{Na}^{+}\right]_{0}$, rectifying potassium; $\left[\mathrm{K}^{+}\right]_{\mathrm{O}}$, extracellular potassium concentration; ${ }^{\left[\mathrm{Na}^{+}\right]_{\mathrm{O}} \text {, }}$ extracellular sodium concentrat
pyrrolidine-2,4-dicarboxylate.

Grant sponsor: National Institutes of Health; Grant numbers: EY06931 EY00379, EY00785.

*Correspondence to: Donald G. Puro, Department of Ophthalmology, Univer sity of Michigan, 1000 Wall Street, Ann Arbor, MI 48105.

E-mail: dgpuro@umich.edu

Received 2 March 1998; Accepted 16J uly 1998 
electroretinogram (ERG). Because slow $P_{I I I}$ is generated by Müller cells responding to changes in the extracellular potassium concentration $\left[\mathrm{K}^{+}\right]_{\mathrm{O}}$ (Ripps and Witkovsky, 1985), it appears that exposure to serum compromises the well-studied (Newman and Reichenbach, 1996) role of Müller cells in maintaining $\mathrm{K}^{+}$ homeostasis in the retina. Hence, a serum-induced dysfunction in the ability of these glia to regulate $\left[\mathrm{K}^{+}\right]_{\mathrm{O}}$ may be one mechanism by which a breakdown in the blood-retinal barrier leads to decreased vision.

In the present study, we investigated the effects on Müller cell currents of plasma, which differs from serum by lacking mol ecules generated during clotting. We report that plasma, like serum, activates an el ectrogenic transporter and inhibits inwardly rectifying potassium $\left(K_{I R}\right)$ channels; these effects were mimicked by glutamate, which is present in both plasma and serum at concentrations of $100 \mu \mathrm{M}$ to $300 \mu \mathrm{M}$ (Ambati et al., 1997; Castillo et al., 1997). However, unlike serum, plasma did not induce a nonspecific cation conductance, which is activated by molecules released during the clotting process (Kusaka et al., 1998). Also, unlike serum, plasma did not inhibit the slow $\mathrm{P}_{\text {III }}$ component of the E RG, which is generated as Müller cells redistribute $\mathrm{K}^{+}$. Thus, it seems likely that Müller cells can maintain $\mathrm{K}^{+}$homeostasis within the retina as they reduce the neurotoxic concentration of glutamate contained in plasma leaking at sites of a breakdown in the blood-retinal barrier.

\section{MATERIALS AND METHODS Fresh Müller Cells}

Freshly dissociated human and bovine Müller cells were prepared as detailed previously (Kusaka et al., 1996). In brief, an $\sim 0.3 \mathrm{~cm}^{2}$ piece of retina was incubated in modified Earle's balanced salt solution (Life Technologies, Grand I sland, NY), 15 units papain (Worthington Biochemicals, Freehold, NJ ), 0.04\% DNase, 2 $\mathrm{mM}$ cysteine, and $12 \%$ chicken serum (Life Technologies) for $40 \mathrm{~min}$ at $30^{\circ} \mathrm{C}$. The piece of retina was then gently triturated, and a suspension of cells was placed on glass coverslip, which was positioned in a recording chamber mounted on the stage of an inverted microscope. Müller cells were identified by their characteristic morphology (Puro et al., 1996). Experiments were performed within $3 \mathrm{~h}$ of cell dissociation.

\section{Patch-Clamp Recordings}

Perforated-patch recordings from fresh Müller cells were made at room temperature $\left(22^{\circ} \mathrm{C}-24^{\circ} \mathrm{C}\right)$. A gravityfed system with multi ple reservoirs was used to continuously perfuse $\left(\sim 2 \mathrm{ml} \mathrm{min}^{-1}\right)$ the recording chamber ( $0.5 \mathrm{ml}$ volume) with various solutions. Whole-cell currents were monitored using the perforated-patch configuration of the patch-clamp technique. Unless noted otherwise, the bathing solution consisted of (in $\mathrm{mM}$ ): $\mathrm{NaCl}, 133 ; \mathrm{KCl}, 10 ; \mathrm{CaCl}_{2}, 1.8 ; \mathrm{MgCl}_{2}, 0.8$; $\mathrm{Na}$-HEPES, 10; and glucose, 20 at $\mathrm{pH}$ 7.4; water was used to lower the osmolarity by $<5 \%$ to $305-310$ mosmol $\mathrm{I}^{-1}$. Patch pipettes were pulled from Corning no. 7052 glass tubing (Gardner Glass Co., Claremont, CA) using a multistage programmable puller (Sutter Instruments, San Rafael, CA), coated with Sylgard no. 184 (Dow Corning, Midland, MI) to within $100 \mu \mathrm{m}$ of their tips and heat polished to tip diameters of 2-3 $\mu \mathrm{m}$. A pipette tip was filled to approximately $400 \mu \mathrm{m}$ from the tip by applying negative pressure to the back end of the pi pette while briefly dipping the tip into the pipette solution, which, unless stated otherwise, consisted of thefollowing (in $\mathrm{mM}$ ): $\mathrm{KCl}, 50 ; \mathrm{K}_{2} \mathrm{SO}_{4}, 65 ; \mathrm{MgCl}_{2}, 6$; and $\mathrm{K}-\mathrm{HEPES}, 10$ at $\mathrm{pH} 7.4$ with the osmol arity adjusted by $<5 \%$ with water to $\sim 285$ mosmol I $^{-1}$. The remainder of the pipette was then backfilled with this solution supplemented with freshly mixed amphotericin B $\left(240 \mu \mathrm{g} \mathrm{ml}^{-1}\right)$ and nystatin $\left(240 \mu \mathrm{g} \mathrm{ml}^{-1}\right)$. The resistances of the pipettes used were 2-5 $\mathrm{M} \Omega$ when tested in the bathing solution. The pipettes were mounted in the holder of a Dagan 3900 patch-clamp amplifier (Dagan Corp., Minneapol is, MN) and sealed to the cell bodies of Müller cells. Seals generally formed during a period of $1-30 \mathrm{~s}$ and reached resistances of $>1 \mathrm{G} \Omega$. As amphotericin and nystatin perforated the patch, the access resistance to the cell decreased to $<20 \mathrm{M} \Omega$ within 20 min for the Müller cells analyzed; the typical series resistance was 12-15 $\mathrm{M} \Omega$ and was not corrected. The membrane resistance of the freshly dissociated bovine Müller cells was $55 \mathrm{M} \Omega(\mathrm{SD}=22 ; \mathrm{n}=10)$ at voltages between $-75 \mathrm{mV}$ and $-97 \mathrm{mV}$. F or human Müller cells, the membrane resistance was $78 \mathrm{M} \Omega(\mathrm{SD}=29 ; \mathrm{n}=8)$; this is not significantly ( $P=0.073$ ) different than the resistance of the bovine cells and is similar to the values reported by others (Francke et al., 1997). With $\mathrm{K}^{+}$ channels blocked, the membrane resistances of the sampled bovine and human Müller cells increased to $>1,200 \mathrm{M} \Omega$.

Currents were evoked by a voltage step protocol or by ramping membrane vol tage ( $66 \mathrm{mV} \mathrm{s}^{-1}$ ) from negative to positive membrane potentials for the construction of continuous current-voltage plots. Currents were filtered at $1 \mathrm{kHz}$ and sampled digitally (at $400 \mu \mathrm{s}$ for steps and 1 millisecond for ramps) using a Lab Master DMA acquisition system (Axon Instruments, Foster City, CA), an IBM-compatible microcomputer (Gateway, North Sioux City, SD), and pCLAMP software (version 6; Axon Instruments), which also controlled voltage protocols and hel ped with data analysis. A scientific plotting program (ORI GIN version 4.1; MicroCal, N orthhampton, MA) was used for data exported from pCLAMP. After data collection, the recorded membrane potentials were corrected for liquid junction potentials, which werecalculated using a computer program (Barry, 1993). The conductances of the K K currents were calculated between $-75 \mathrm{mV}$ and $-97 \mathrm{mV}$. The amplitudes of the inward currents were measured at $-74 \mathrm{mV}$, which is the Nerstian value for the equilibrium potential of potassium. 


\section{Electroretinography}

As detailed previously (Kusaka et al., 1998), ERG recordings were made from retinas isolated from darkadapted adult Sprague-Dawley rats. Advantages of using the rodent retina, as opposed to bovine or human tissue, include the ability to maintain dark-adapting conditions before death and to record from the retinas immediately after death. The rat retina is a good model because it is vascularized, as is the human retina. Although it would be ideal to correlate Müller cell physiology with ERGs from the same species, we have been unable to consistently obtain satisfactory perforated-patch recordings from freshly dissociated rat Müller cells.

A $\sim 10-\mathrm{mm}^{2}$ portion of the isolated retina was positioned with the photoreceptor side in a chamber perfused at a flow rate of $3 \mathrm{ml} \mathrm{min-1}$ with the oxygenated bathing solution consisting of the following (in $\mathrm{mM}$ ): $\mathrm{NaCl}, 110 ; \mathrm{KCl}, 5 ; \mathrm{Na}_{2} \mathrm{HPO}_{4}, 0.8 ; \mathrm{NaH}_{2} \mathrm{PO}_{4}, 0.1$; $\mathrm{NaHCO}_{3}, 30 ; \mathrm{MgSO}_{4}, 1 ; \mathrm{CaCl}$, 1.8; glutamine, 0.25; and glucose, 22 at $36.6^{\circ} \mathrm{C} \pm 0.5^{\circ} \mathrm{C}$ and $\mathrm{pH} 7.50 \pm 0.05$. An antifoaming agent ( $\sim 100 \mathrm{ppm}$ Antifoam $\mathrm{A})$ was added to the perfusion reservoirs. With $10 \%(\mathrm{vol} / \mathrm{vol})$ plasma, the osmolarity of the perfusate changed by $<1 \%$. To monitor the slow $\mathrm{P}_{\mathrm{II}}$ component of the ERG, 2-amino-4phosphonobutyric acid (APB; $50 \mu \mathrm{M}$ ) was added to the perfusate to block the b-wave as described el sewhere (Kusaka et al., 1998). After establishing that the peak amplitude of sl ow $\mathrm{P}_{\text {III }}$ was stable $(<3 \%$ maximal change in $5 \mathrm{~min}$ ), the retina was exposed for at least $7 \mathrm{~min}$ to the APB-containing perfusate supplemented with $10 \%$ plasma.

Recordings were made using a glass micropipette filled with the bathing solution and positioned at the tips of the outer segments and referenced to a Ag-AgCl el ectrode located under the retina. Transretinal ERGs were evoked by electronic flashes $(\sim 0.5$-millisecond duration) of monochromatic light (500 nm). Potentials from the isol ated retina were recorded with a high-gain amplifier (Cyber Amp 320; Axon Instruments), filtered at $400 \mathrm{~Hz}$, and digitized; a minicomputer was used for data storage and analysis.

\section{Dialysis}

Cellulosemembranetubing (Spectrum Medical Industries, Laguna Hills, CA) with a molecular cutoff of 1,000 Da was used for dialysis as detailed by Kusaka et al . (1998).

\section{Chemicals}

Chemicals and bovine serum werefrom Sigma Chemical Co. (St. Louis, MO) unless otherwise noted. Human serum was donated by one of the authors (D.G.P.).

\section{Ocular Tissue}

Sprague-Dawley rats were bred in colonies at the University of Michigan and were maintained under conditions of reduced lighting. Animal use conformed with the guidelines of the Society for Neuroscience. Bovine eyes were obtained soon after near-instantaneous death induced at a local licensed abattoir. Donor adult human eyes were supplied within $24 \mathrm{~h}$ post mortem by the Midwest Eye Bank and Transplantation Center (Ann Arbor, MI) or the National Disease Research Interchange (Philadel phia, PA), both of which obtained proper consent from relatives. Study protocols were approved by the University of Michigan Institutional Review Board and Committee on the Use and Care of Animals.

\section{RESULTS \\ Plasma Alters Müller Cell Currents}

We used the perforated-patch technique to assess whether plasma induces changes in the whole-cell currents of freshly dissociated bovineand human Müller cells. To facilitate comparison with our recent study in which $10 \%(\mathrm{vol} / \mathrm{vol})$ serum was used (Kusaka et al., 1998), we examined the effects of $10 \%$ plasma. With exposure of Müller cells to plasma, both the inward and outward currents of the Müller cells decreased (Fig. IA and B). These effects of plasma were reversible. Similar results were observed in each of five human and five bovine Müller cells sampled. Associated with the plasma-induced changes in Müller cell currents, the membrane potential depolarized significantly ( $\mathrm{P}=$ 0.033 ) from $-71 \mathrm{mV}(\mathrm{SD}=2.8 \mathrm{mV})$ to $-67 \mathrm{mV}$ (SD = $4.7 \mathrm{mV}$ ). In control experiments, no effect on the current-vol tage (I-V) relati onships or membrane potentials of Müller cells ( $\mathrm{n}=3$ bovine cells) was detected when the cells were exposed to heparin, which was added $(1.43 \mathrm{U} / \mathrm{ml})$ to the collected blood to prevent clotting.

Digital subtraction of the current traces obtained in the absence and presence of plasma showed both transient and sustained components of the plasma-sensitive current (Fig. 1C, inset). In this study, we focused on the sustained currents, which for Müller cells are more meaningful physiologically (Newman, 1993). The I-V relationship for the sustained component of the plasmasensitive current showed strong inward rectification (Fig. 1D). This rectification suggested that plasma inhibits the $K_{I R}$ current, the principal conductance of Müller cells (Brew et al., 1986; Newman 1993; Puroand Stuenkel, 1995). However, the change in current was modest and was observed only at the most hyperpolarized potential tested in Fig. 1D.

Interestingly, as is evident in Fig. 1D, the reversal potential of the sustained current induced by plasma was more negative than the equilibrium potentials for $\mathrm{K}^{+}\left(\mathrm{E}_{\mathrm{K}}=-74 \mathrm{mV}\right), \mathrm{Cl}^{-}\left(\mathrm{E}_{\mathrm{Cl}}=-22 \mathrm{mV}\right)$, or other ions. To account for such a hyperpolarized reversal potential, 

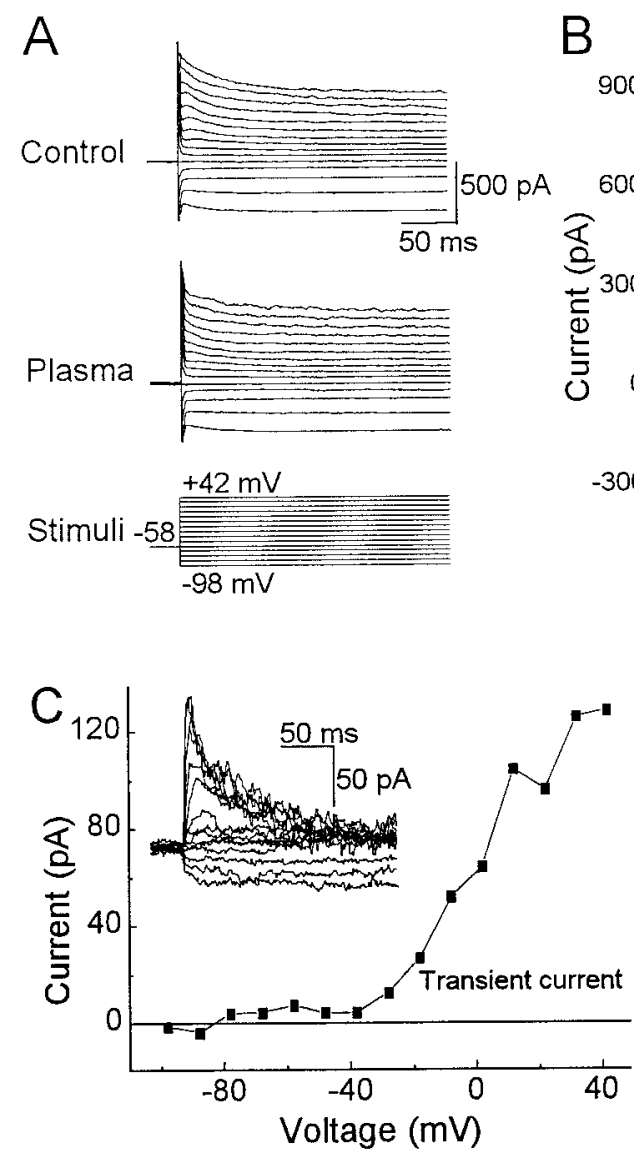

Fig. 1. Effect of human plasma on currents in a freshly dissociated human Müller cell monitored with a perforated-patch recording. A: Currents evoked during a control period and during exposure to $10 \%$ plasma. The clamp protocol is shown below. B: I-V relationship of the currents shown in A. The current amplitudes used were the peak values. C: I-V relationship for the transient component of the current inhibited by plasma. The current amplitudes used were the differences

we postulated that this sustained response of Müller cells was the net result of the effects of plasma on two or more currents. Our subsequent experiments showed that a plasma-induced inhibition of the $K_{I R}$ current is partially masked by an inward current. This inward current is generated by an electrogenic glutamate transporter, which is activated with exposureto plasma.

\section{Two Components of the Sustained Response}

To hel p characterize the sustained response of Müller cells to plasma, we compared the effects of plasma in the absence and presence of barium, which is a potent bl ocker of $\mathrm{K}^{+}$channels (Hille, 1992) (Fig. 2A-D). In the absence of $\mathrm{Ba}^{2+}$, plasma induced a net inhibition of current (Fig. 2A and B). However, in the presence of $\mathrm{Ba}^{2+}$, a current activated by plasma was observed ( $\mathrm{Fig}$. $2 \mathrm{C}$ and $\mathrm{D}$ ). This $\mathrm{Ba}^{2+}$-insensitive current was inward at depolarized potentials and did not clearly reverse (Fig. 2D).
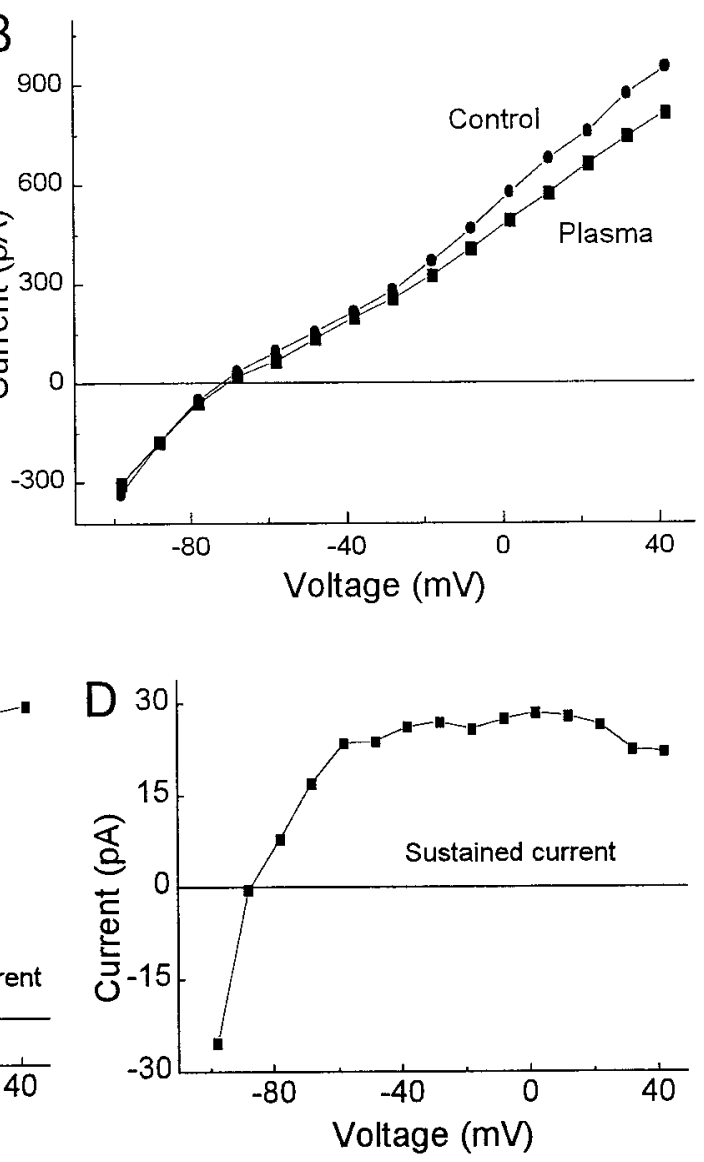

between the peak current and the mean current, which was determined at 200-275 milliseconds after a voltage step. Inset: Plasmasensitive currents obtained by digital subtraction of the traces shown in (A). D: I-V plot of the sustained component of the plasma-sensitive current. Exposure to plasma affects both transient and sustained currents in Müller cells.

From the experimentally derived I-V plots of the net current affected by plasma (Fig. 2B) and of the plasmaactivated current (Fig. 2D), we could calculate the I-V relationship of the conductance that was inhibited by plasma (Fig. 2E). The difference between the net current (Fig. 2B) and the activated current (Fig. 2D) was a $\mathrm{Ba}^{2+}$-sensitive current with steep inward rectification and a reversal potential near $E_{K}$, i.e., characteristics of the $K_{I R} 4.1$ channels expressed by mammalian Müller cells (I shii et al., 1997; Kusaka and Puro, 1997). Observations similar to those shown in Fig. 2 were made in four Müller cells (three bovine and one human). In this series, the $\mathrm{K}_{\mathrm{IR}}$ conductance was inhibited by $11 \%$ (SD = $4 \%$, measured between $-75 \mathrm{mV}$ and $-97 \mathrm{mV}$ ) when $\mathrm{Mül}$ ler cells were exposed to plasma; the $\mathrm{Ba}^{2+}{ }_{-}$insensitive current activated by plasma had a mean amplitude of $20 \mathrm{pA}(\mathrm{SD}=4)$ at $\mathrm{E}_{\mathrm{K}}$, i.e., $-74 \mathrm{mV}$. These experiments indicate that the sustained effect of plasma is the net result of an inhibition of $K_{I R}$ channels and the activation of an inward current. 

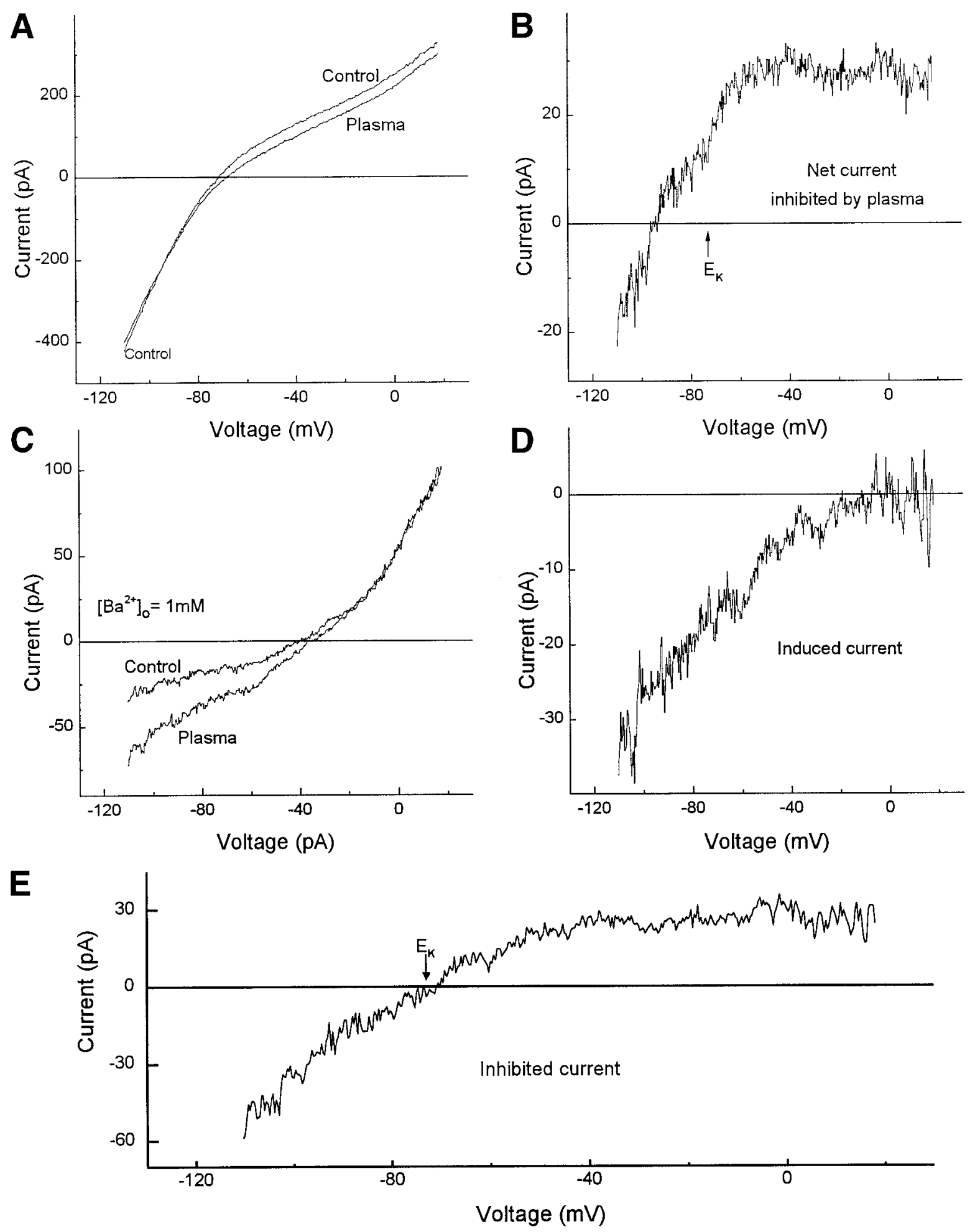

Fig. 2. Effect of $\mathrm{Ba}^{2+}$ on the plasma-sensitive currents. A: Currents evoked in bovine Müller cells during a control period and during exposure to $10 \%$ plasma. Currents were monitored by perforatedpatch recording and evoked by ramping membrane voltage. B: I-V relationship for the current calculated by subtracting currents recorded in the presence of plasma from those recorded under control conditions. C: Currents evoked in the absence or presence of plasma in a bathing solution supplemented with $\mathrm{BaCl}_{2}(1 \mathrm{mM})$ to block $\mathrm{K}_{\mathrm{IR}}$ channels and 4-aminopyridine ( $5 \mathrm{mM})$ to block transient outward potassium $\left(\mathrm{K}_{\mathrm{A}}\right)$ channels. D: Plot of the difference between the I-V curves shown in (C); this shows the plasma-activated current, which is insensitive to $\mathrm{Ba}^{2+}$. E: I-V relationship calculated by removing the contribution of the plasma-induced current shown in $D$ from the net inhibited current shown in B; this shows the current inhibited by plasma. Plasma inhibits $K_{I R}$ channels and activates an inward current in Müller cells. 

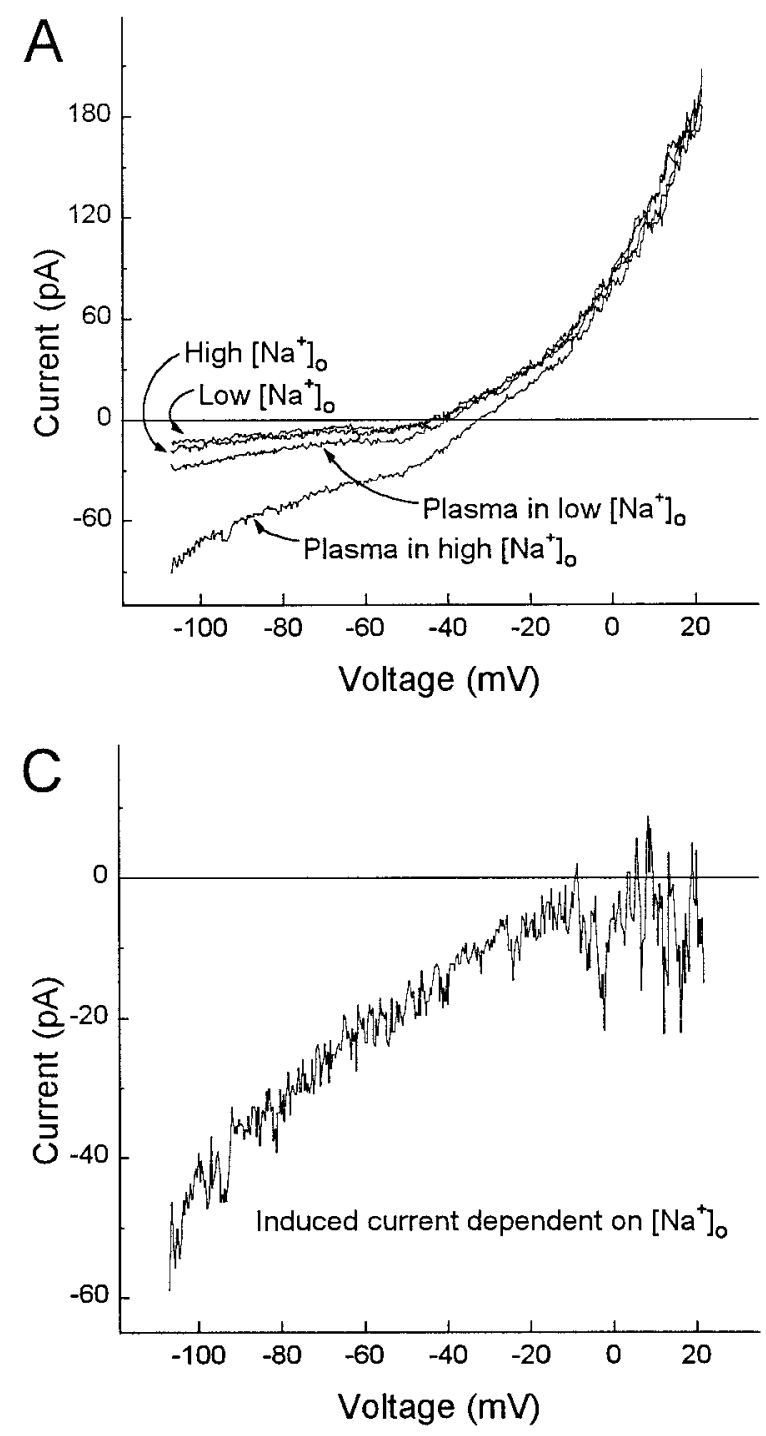

The Plasma-Activated Current

It was important to characterize the inward current activated when Müller cells are exposed to plasma. The voltage dependence and lack of a reversal potential suggested that an electrogenic transporter may account for this inward current. Becausea number of transporters are dependent on the presence of extracellular sodium, we examined the effect of reducing the extracellular sodium concentration $\left(\left[\mathrm{Na}^{+}\right]_{0}\right)$ on the plasmaactivated inward current. Perforated-patch recordings of Müller cells were made in a bathing sol ution containing 4-aminopyridine and $\mathrm{Ba}^{2+}$ to block transient outward potassium $\left(\mathrm{K}_{\mathrm{A}}\right)$ and $\mathrm{K}_{\mathrm{IR}}$ channels, respectively. As shown in Fig. 3, reducing $\left[\mathrm{Na}^{+}\right]_{0}$ markedly diminished the amplitude of the inward current induced by plasma. In a series of five bovine Müller cells, the plasmainduced current was reduced by $75 \%(S D=4 \%)$ in the low $\left[\mathrm{Na}^{+}\right]_{0}$ bathing solution. These finding are consistent with plasma activating an $\mathrm{Na}^{+}$-dependent el ectrogenic transporter.

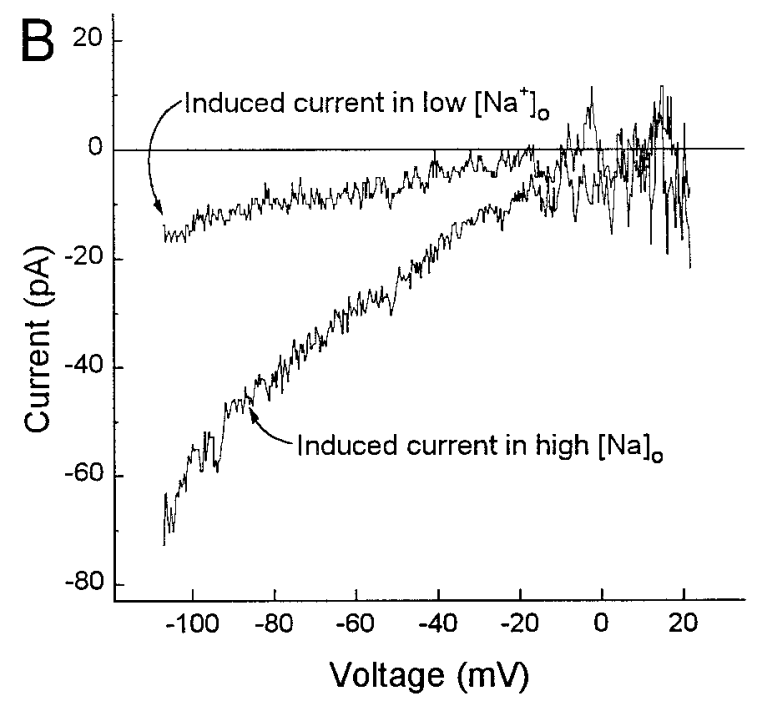

Fig. 3. Effect of $\left[\mathrm{Na}^{+}\right]_{0}$ on the plasma-activated inward current. A: I-V relationships of a bovine Müller cell in high $\left[\mathrm{Na}^{+}\right]_{0}$ or low $\left[\mathrm{Na}^{+}\right]_{\mathrm{O}}$ and in the presence or absence of $10 \%$ plasma. The high $\left[\mathrm{Na}^{+}\right]_{0}$ bathing solution contained $133 \mathrm{mM} \mathrm{Na}{ }^{+}$. In the low $\left[\mathrm{Na}^{+}\right]_{0}$ experiments, the $\mathrm{NaCl}$ in the bathing solution was replaced with choline chloride, and N-methyl-D-glucamine-HEPES was substituted for $\mathrm{Na}$ HEPES; with $10 \%$ plasma, the estimated $\mathrm{Na}^{+}$concentration was 14 mmol $\mathrm{I}^{-1}$. Both solutions contained $\mathrm{BaCl}_{2}(1 \mathrm{mM})$ and 4-aminopyridine (5 mM) to block $K_{I R}$ and $K_{A}$ currents, respectively. B: Plots of the difference between the I-V curves in (A). C: Plot of the difference between the I- $V$ curves in (B). The inward current activated by plasma is dependent on $\left[\mathrm{Na}^{+}\right]_{0}$.

One well-characterized, $\mathrm{Na}^{+}$-dependent transporter in Müller cells is the glutamate transporter (Brew and Attwell, 1987; Billups et al., 1996). Because this transporter is competitively blocked by I-trans-pyrrolidine2,4-dicarboxylate (PDC; Sarantis et al., 1993), wetested the effect of exposing Müller cells to PDC (100 $\mu \mathrm{M})$ before the addition of plasma to the perfusate. As shown in Fig. 4, the plasma-induced current was reduced profoundly under these conditions; in a series of five Müller cells (three bovine and two human), PDC inhibited the plasma-induced inward current by $99 \%$ $(\mathrm{SD}=2)$.

This near total inhibition of the plasma-induced current is in contrast to the effect of PDC on the currents activated by serum. Figure $4 C$ and $D$ shows that $10 \%$ serum induced a PDC-insensitive current, as well as a PDC-sensitive component. In a series of four bovine Müller cells, PDC inhibited the serum-induced current by $45 \%(S D=8)$, which was significantly less than the $99 \%$ inhibition of the plasma-activated current 

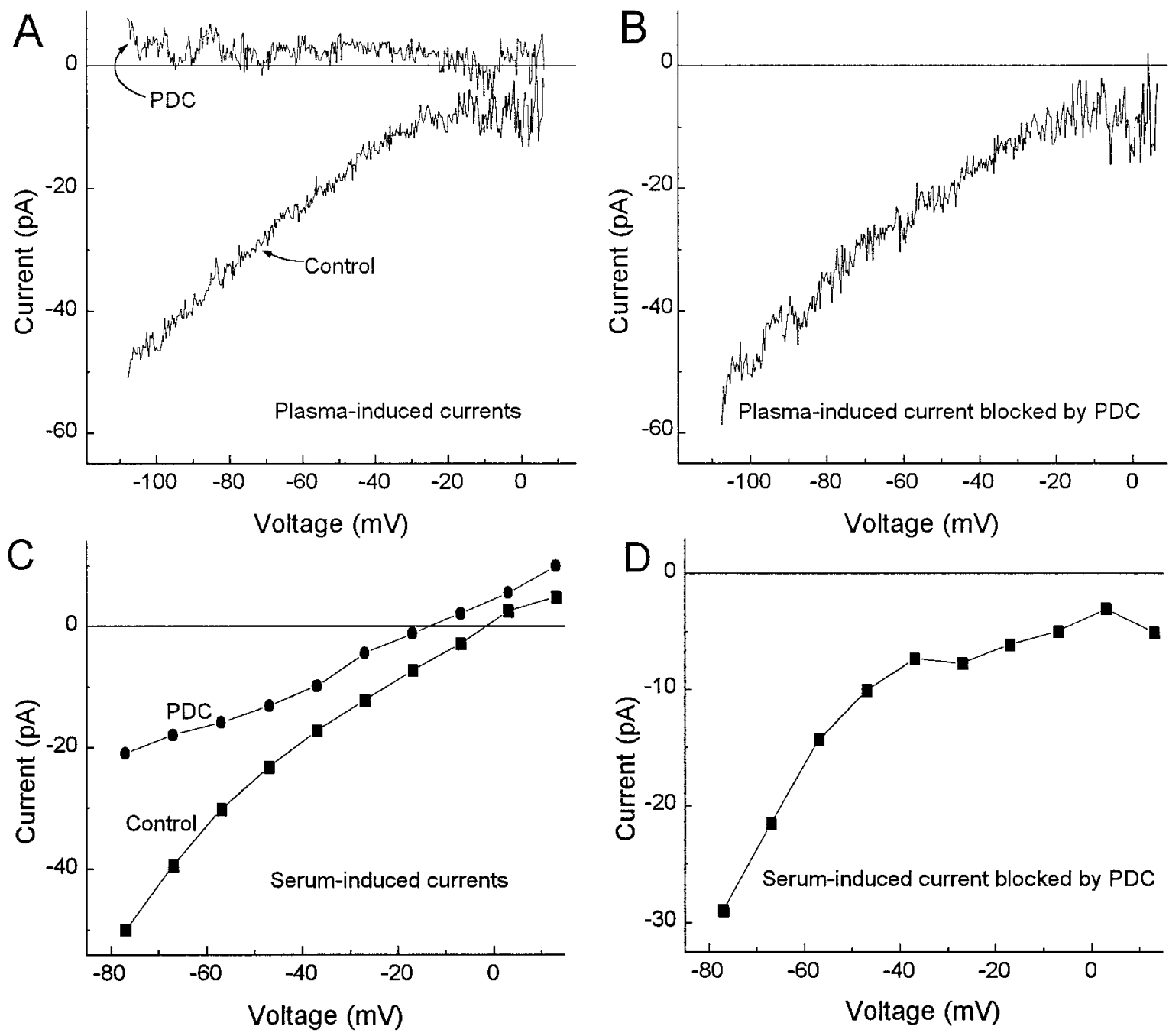

Fig. 4. Effect of PDC on Müller cell currents activated by plasma and serum. A: I-V plots of the currents induced in a bovine Müller cell exposed to $10 \%$ plasma in the presence or absence of PDC $(100 \mu \mathrm{M})$, a blocker of the glutamate transporter. B: Plot of the difference between the I-V curves in (A). C: I-V plots of currents induced in a bovine Müller cell exposed to $10 \%$ serum in the presence or absence of $100 \mu \mathrm{M}$

( $P<0.001$ ). Based on our recent study of the effect of serum on Müller cells (Kusaka et al., 1998), this PDC-insensitive conductance is caused by a nonspecific cation (NSC) conductance that is activated by serumderived molecules such as lysophosphatidic acid (molecular weight of $436 \mathrm{Da}$ ). We also found that the removal from serum of molecules with molecular weights of $<1,000 \mathrm{Da}$ reduced the induced inward current by $98 \%$, i.e., from $43 \mathrm{pA}(\mathrm{SD}=16 \mathrm{pA} ; \mathrm{n}=38$ ) to $1 \mathrm{pA}(\mathrm{SD}=3 \mathrm{pA} ; \mathrm{n}=13)$. This indicates that serumderived molecules of molecular weights of $<1,000 \mathrm{Da}$ can activate the PDC-sensitive current (i.e., the glutamate transporter) and the PDC-insensitive current (i.e., NSC channels) in Müller cells.

Additional evidence for plasma activating the glutamate transporter is that glutamate qualitatively mimicked the effect of plasma in each of the five bovine Müller cells tested under conditions in which $\mathrm{K}^{+}$cur-

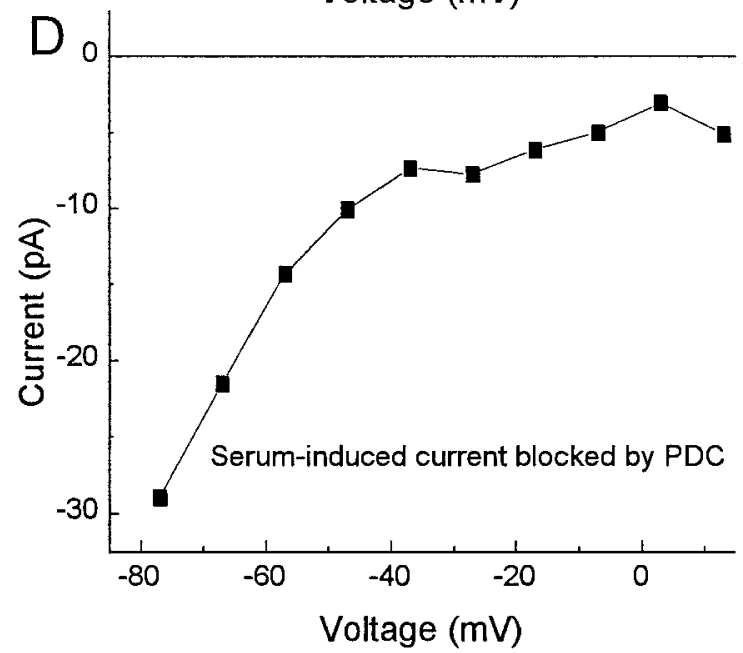

PDC. D: Plot of the difference between the I-V curves in (C). Voltage ramps were used in (A) and voltage steps in (C). The bathing solutions contained $\mathrm{BaCl}_{2}$ and 4-aminopyridine as in Fig. 3. PDC blocks virtually all of the inward current induced by plasma but only partially blocks the current induced by serum.

rents were blocked (Fig. 5A). We further reasoned that if the plasma-induced current was caused by the activation of the glutamate transporter, then maximally activating this transporter by adding glutamate to the bathing solution should limit the subsequent response of a Müller cell to plasma. As shown in Fig. 5B, the presence of $250 \mu \mathrm{M}$ glutamate in the bathing solution prevented an induction of an inward current by plasma. In four of four bovine Müller cells tested, no plasmainduced current was detected when the cells were preexposed to glutamate. Our observations that the plasma-induced current is $\mathrm{Na}^{+}$dependent, blocked by PDC, mimicked by glutamate, and not additive to a maximal glutamateinduced current strongly indicate that plasma activates the glutamatetransporter of Müller cells.

In addition to the activation of this transporter, the experimental findings presented in this study show that plasma inhibits $K_{I R}$ channels and a transient 


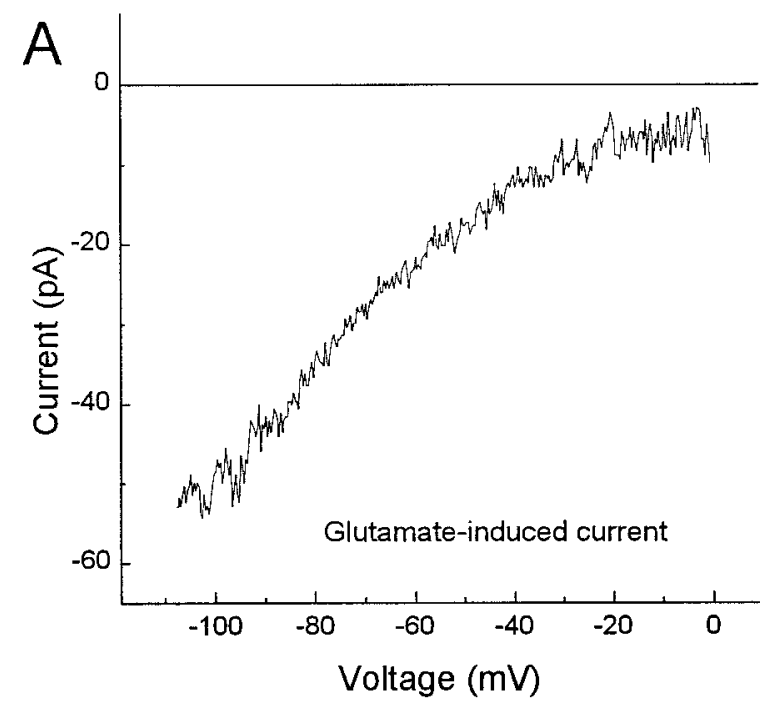

Fig. 5. Effect of glutamate on the plasma-induced, $\mathrm{Ba}^{2+}$-insensitive current. A: I-V relationship of the current induced in a bovine Müller cell exposed to $20 \mu \mathrm{M}$ glutamate. B: I-V plots of the currents induced by plasma in the presence or absence of glutamate $(250 \mu \mathrm{M})$. All

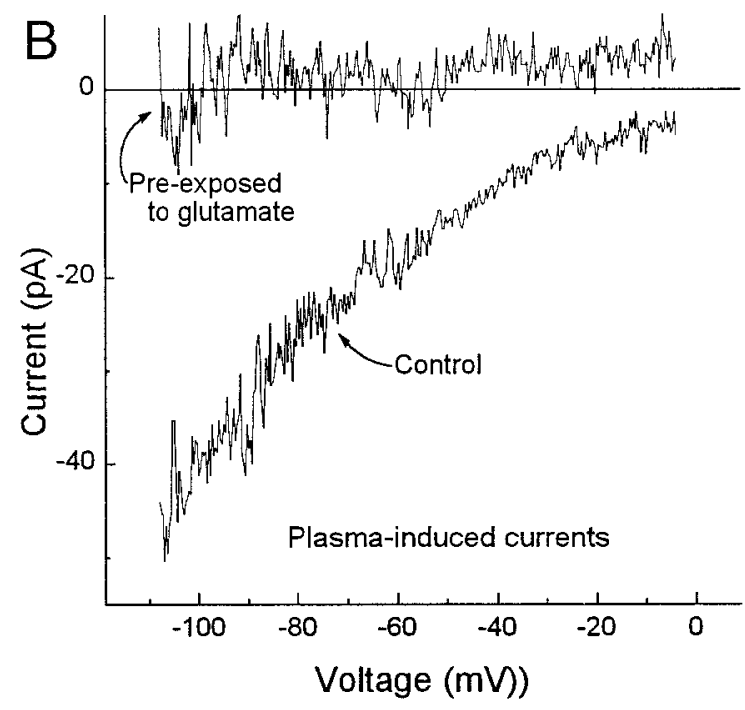

bathing solutions contained $\mathrm{BaCl}_{2}(1 \mathrm{mM})$ and 4-aminopyridine $(5 \mathrm{mM})$. Exposure of Müller cells to glutamate activates an inward current and prevents plasma from inducing a current.

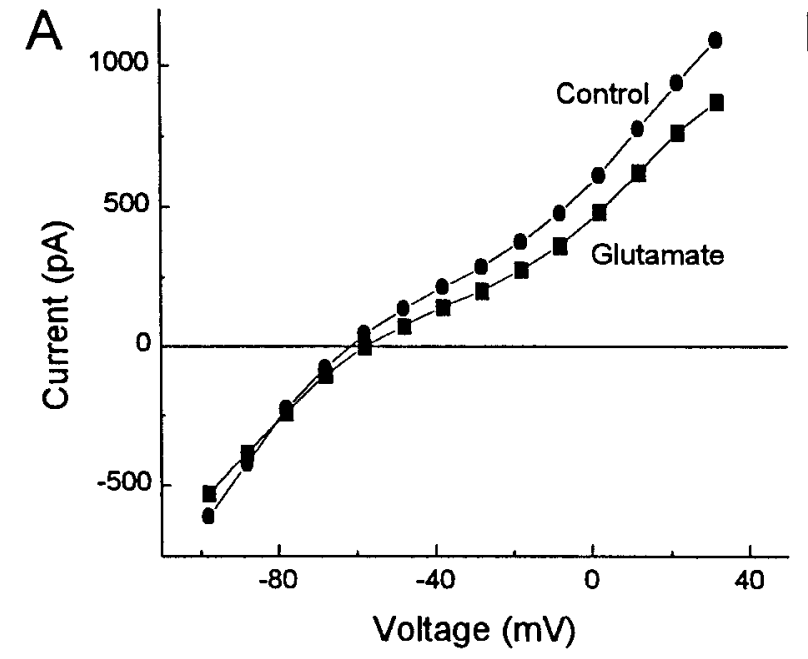

Fig. 6. Effect of glutamate on currents in a human Müller cell. A: I-V relationships of the currents in the absence and presence of glutamate $(20 \mu \mathrm{M})$. The current amplitudes used were the peak values. B: I-V plots of the peak $(\mathbf{\square})$ and sustained $(\bullet)$ amplitudes of the current inhibited by glutamate. Values for the sustained currents are

outward current, which is likely to be caused by $\mathrm{K}_{\mathrm{A}}$ channels (Newman, 1985). The question arises as to what mol ecule(s) in plasma accounts for these effects on Müller cells. Because plasma contains a significant concentration of glutamate $(\sim 100-300 \mu \mathrm{M}$; Castillo et al., 1997), a parsimonious hypothesis is that this amino acid is likely to be one of the active molecules. Consistent with this hypothesis, we found that $20 \mu \mathrm{M}$ glutamate (Fig. 6) mimicked the effects of $10 \%$ plasma (Fig. 1B). These effects included a change in the sustained currents as well as an inhibition of a transient outward current (Fig. 6B, inset). Additional support for glutamate being an active component of plasma is that

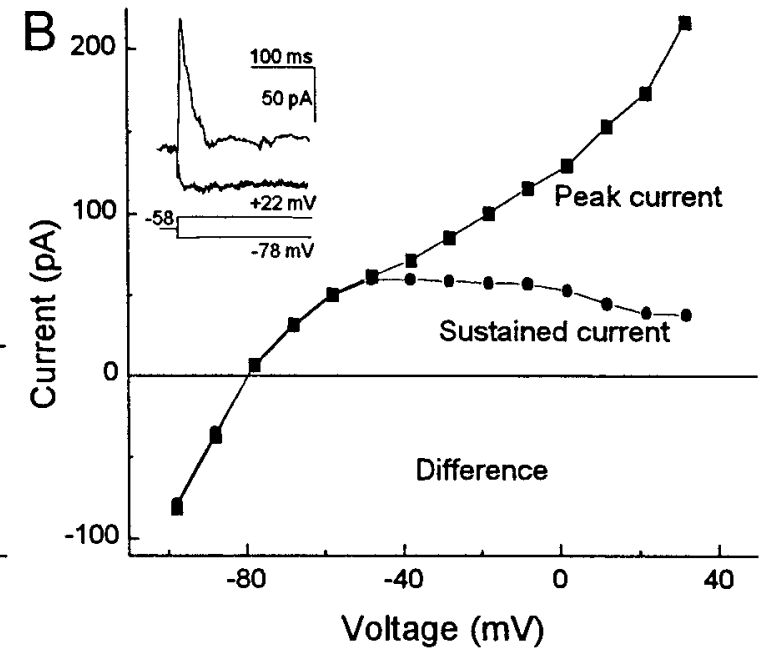

the mean amplitude during the final 75 milliseconds of each voltage step. Inset: The glutamate-sensitive current calculated by digital subtraction of the currents elicited by voltage steps from -58 to -78 $\mathrm{mV}$ and $+22 \mathrm{mV}$. Glutamate induces changes in Müller cell currents that are similar to those induced by plasma.

this amino acid is known to inhibit Müller cell $K_{I R}$ channels (Schwartz, 1993; Puro et al., 1996). Thus, it seems likely that the observed effects of plasma on Müller cell currents are mediated, at least in part, by glutamate.

\section{Plasma and the ERG}

An inhibition of $\mathrm{K}^{+}$channels and an activation of the electrogenic glutamate transporter could, at least theoretically, affect the ability of Müller cells to redistribute $\mathrm{K}^{+}$. To help examine this possibility, we assessed the 


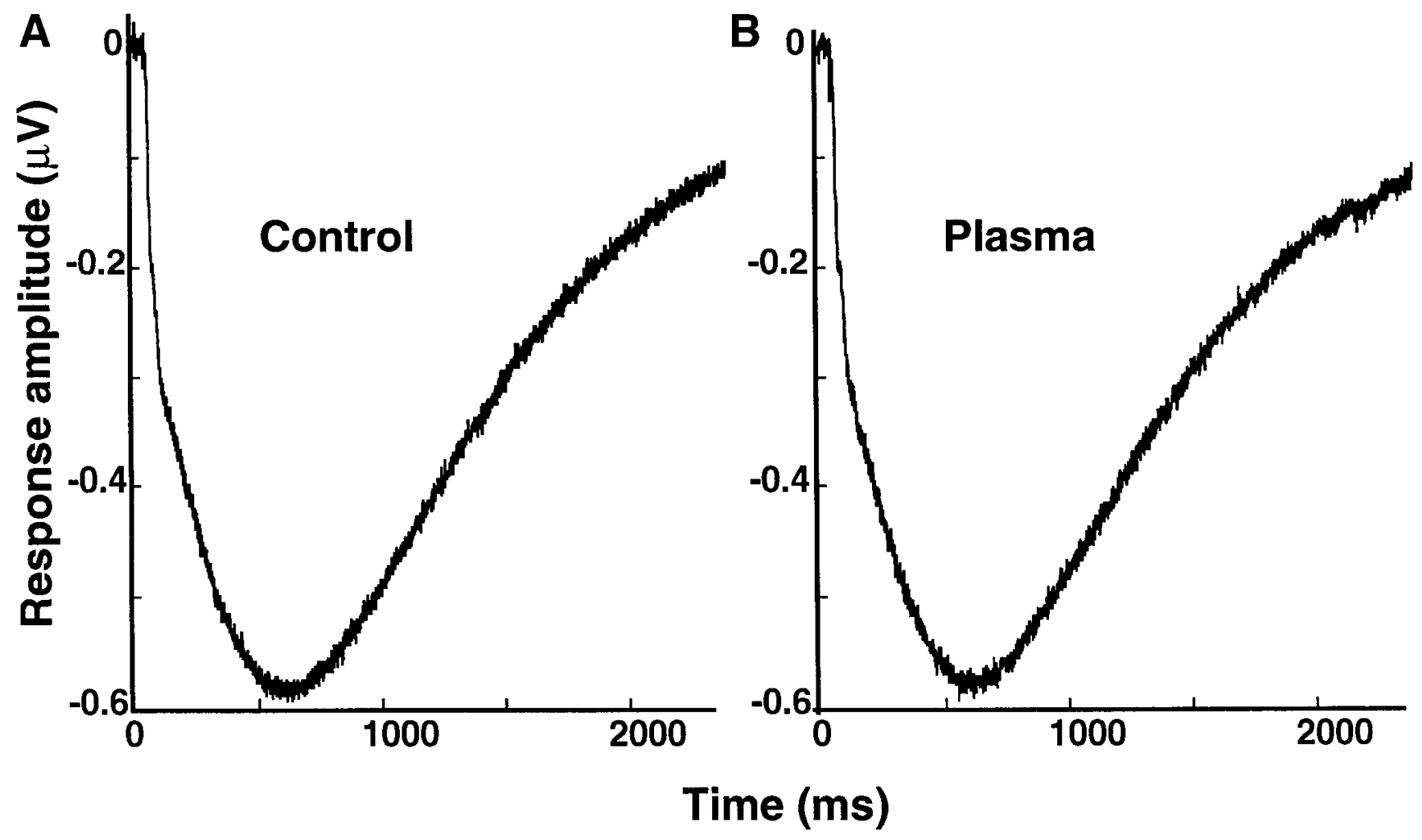

Fig. 7. Effect of plasma on the slow $P_{111}$ component of the ERG. Responses of an isolated rat retina at (A) 1 min before and (B) $10 \mathrm{~min}$ after exposure to $10 \%$ plasma. The perfusate contained 2-amino-4phosphonobutyric acid $(50 \mu \mathrm{M})$, which blocked the b-wave of the ERG

effect of plasma on the slow $P_{\text {III }}$ component of the ERG. This component was selected because there is general agreement (Ripps and Witkovsky, 1985; Karwoski et al., 1996) that slow $P_{11}$ is generated by the response of Müller cells to a light-evoked change in the extracellular concentration of $\mathrm{K}^{+}$(Oakley and Green, 1976). A possible effect of plasma on slow $\mathrm{P}_{\mathrm{III}}$ is also of interest because we recently reported that $10 \%$ serum inhibits this component of the ERG (Kusaka et al., 1998).

In a series of experiments, slow $\mathrm{P}_{\mathrm{III}}$ was recorded from the isolated rat retina as detailed previously (Kusaka et al., 1998). During exposure to $10 \%$ plasma, we did not detect any changes in thetemporal characteristics of slow $P_{I I I}$ (Fig. 7). Also, the amplitude of slow $P_{I I I}$ changed minimally; the peak voltage increased by $1.6 \%$ $(S D=3 \% ; n=3)$. This is significantly $(P<0.001)$ different than the effect of $10 \%$ serum which reversibly reduced the peak amplitude by $21 \%(S D=2 ; n=4)$ as reported recently (Kusaka et al., 1998). Thus, plasma, unlike serum, did inhibit the sl ow $\mathrm{P}_{\mathrm{III}}$ component of the ERG.

\section{DISCUSSION}

Our perforated-patch recordings from freshly dissociated human and bovine Müller cells show that plasma activates an electrogenic transporter and inhibits $K_{I R}$ and, thereby, showed the slow $\mathrm{P}_{\mathrm{III}}$ component. For both (A) and (B), there was a brief ( $\sim 0.5$ millisecond) flash of light at time zero; the intensity of the flash was $3.05 \mathrm{log}$ quanta rod $^{-1}$ flash $^{-1}$. Plasma does not affect the slow $P_{I I I}$ component of the ERG.

channels, as well as a transient outward current. In this study, we focused on the sustained currents affected by plasma. One reason for this emphasis is that the sustained currents are active near the resting membrane potential. In contrast, the transient current has a threshold of activation of $-40 \mathrm{mV}$ (Fig. 1C). Also, because a leakage of plasma into the retina occurs for relatively long durations, the sustained effects on glial physiology are of particular significance.

It appears likely that these effects on Müller cell currents are induced, at least in part, by glutamate, which is normally present in the plasma at concentrations of approximately 100-300 $\mu \mathrm{M}$ (Castillo et al., 1997). In agreement with a role for glutamate, it is known that this amino acid activates the L-glutamate/ L-aspartate transporter 1 (GLAST-1) that is expressed by Müller cells (Rauen et al., 1996; Lehre et al., 1997; Rauen et al., 1998) and is electrogenic (Brew and Attwell, 1987). During the transport of glutamate, a net inward current is generated as two $\mathrm{Na}^{+}$ions enter, but only one $\mathrm{K}^{+}$exits; the influx of the negatively charged amino acid is balanced with either an exiting $\mathrm{OH}^{-}$or an entering $\mathrm{H}^{+}$(Billups et al., 1996). Our experiments using low $\left[\mathrm{Na}^{+}\right]_{\mathrm{O}}$, which is required for GLAST function; PDC, which is a GLAST blocker; or glutamate, which mimicked and blocked the effects of plasma, provide strong evidence that the glutamate contained in plasma can activate GLAST and, thereby, induce a 
depolarizing inward current in Müller cells. In addition to inducing the GLAST current, glutamate is known to reduce the $K_{I R}$ current of these glia by mechanisms involving the activation of glutamergic receptors (Schwartz, 1993; Puro et al., 1996). Also, our finding that glutamate and plasma have similar inhibitory effects on the transient outward current of Müller cells lends further support to the likel ihood that the plasmainduced changes detected in these glia are mediated, at least in part, by this amino acid.

We considered the possibility that plasma affects the role of Müller cells in maintaining $\mathrm{K}^{+}$homeostasis. By a specialized mechanism of $\mathrm{K}^{+}$buffering, termed $\mathrm{K}^{+}$ siphoning (Newman et al., 1984), $\mathrm{K}^{+}$enters a Müller cell where $\left[\mathrm{K}^{+}\right]_{\mathrm{O}}$ is high and exits where $\left[\mathrm{K}^{+}\right]_{\mathrm{O}}$ is lower. It seemed possible that this siphoning of $\mathrm{K}^{+}$via Müller cells could be diminished when plasma inhibits $K_{I R}$ channels, the chief pathways for the redistribution of $\mathrm{K}^{+}$via these glia (Brew et al., 1986; Newman, 1993). Also, the depolarization caused by the activation of GLAST would reduce the electrochemical gradient for an influx of $\mathrm{K}^{+}$. However, despite a partial inhibition of $\mathrm{K}_{\mathrm{IR}}$ channels and a 4-mV depolarization of the membrane potential, the ERG of the isolated retina did not show a detectable effect of plasma on the slow $\mathrm{P}_{11 \mathrm{I}}$ component, which is generated by the response of Müller cells to a light-evoked change in $\left[\mathrm{K}^{+}\right]_{0}$ (Ripps and Witkovsky, 1985). It may be that the effects of plasma that tend to diminish $\mathrm{K}^{+}$redistribution are balanced by actions that enhance transretinal $\mathrm{K}^{+}$currents. For example, depolarization increases the el ectrochemical gradient for $\mathrm{K}^{+}$efflux, which may be a limiting step in the redistribution of $\mathrm{K}^{+}$via the steeply rectifying $K_{I R}$ channels of Müller cells. In addition, as we theorized el sewhere (Puro and Stuenkel, 1995), a partial inhibition of $K_{I R}$ channels would increase the length constant of the membrane and, thereby, could enhance the flow of $\mathrm{K}^{+}$from the vitreal endfoot of the Müller cell. Our inability to detect a significant change in the sl ow $P_{1 I I}$ component of the ERG suggests that the redistribution of $\mathrm{K}^{+}$via Müller cells is minimally affected by $10 \%$ plasma.

The concentration of plasma at sites of a breakdown in the blood-retinal barrier in vivo is unknown. Although plasma accounts for approximately $50 \%$ of the blood components, it seems likely that fluid leaking from the vascular system would be diluted as it enters the extracel lular space of the retina. Hence, our testing of $10 \%$ plasma may be real istic. Also, this concentration facilitated comparison with our previous study (Kusaka et al., 1998) in which we used $10 \%$ serum, which elicits a maximal effect because we found that concentrations of $5 \%, 10 \%$, or $20 \%$ were equally potent in inducing changes in the Müller cell currents.

In contrast to plasma, serum does inhibit slow $\mathrm{P}_{\text {III }}$ (Kusaka et al., 1998) and, thus, appears to diminish the siphoning of $\mathrm{K}^{+}$by Müller cells. Although serum contains glutamate at a concentration similar to that of plasma (Ambati et al., 1997; Castillo et al., 1997), molecular products of the clotting response are also present and almost certainly are the reason that serum affects the slow $P_{I I I}$ component of the ERG, whereas plasma does not. More specifically, we recently found that Iysophosphatidic acid, which is released from platel ets during clotting, activates an NSC conductance and partially inhibits $K_{I R}$ channels in bovine and human Müller cells (Kusaka et al., 1998). With activation of the NSC channels, the transcellular $\mathrm{K}^{+}$flux occurring in response to a change in $\left[\mathrm{K}^{+}\right]_{0}$ can be balanced, at least in part, by the movement of $\mathrm{Na}^{+}$and $\mathrm{Ca}^{2+}$. As a result, the transretinal $\mathrm{K}^{+}$current and the siphoning of $\mathrm{K}^{+}$by Müller cells is reduced. Also, the lysophosphatidic acid-induced inhibition of $\mathrm{K}_{\mathrm{IR}}$ channels combined with the inhibition of these channels by the glutamate contained in the blood would further limit the pathways for $\mathrm{K}^{+}$redistribution via these glia. Our finding that serum more profoundly affects Müller cell physiology correlates with the clinical observation that the presence of hemorrhages at sites of vascular leakage is associated with a greater reduction in retinal function (Gass, 1997).

\section{ACKNOWLEDGMENTS}

This work was supported by grants EY06931, EY00379, and EY00785 from the National Institutes of Health. Dr. Puro is a Research to Prevent Blindness Senior Scientific I nvestigator.

\section{REFERENCES}

Ambati J , Chalam KVV, Chawla DK, D'Angio CT, Guillet EG, Rose SJ , Vanderlinde RE, Ambati BK. 1997. Elevated $\gamma$-aminobutric acid, glutamate, and vascular endothelial growth factor levels in the vitreous of patients with proliferative diabetic retinopathy. Arch Ophthalmol 115:1161-1166.

Barry PH. 1993. J PCalc, a software package for calculating liquid junction potential corrections in patch-clamp, intracellular, epithe lial and bilayer measurements and for correcting junction potential measurements. J Neurosci Meth 51:107-116.

Billups B, Rossi D Attwell D. 1996. Anion conductance behavior of the glutamate uptake carrier in salamander retinal glial cells. J Neurosci 16:6722-6731.

Brew H, Attwell D. 1987. Electrogenic glutamate uptake is a major current carrier in the membrane of axolotl retinal glial cells. Nature 327:707-709.

Brew H, Gray PTA, Mobbs P, Attwell D. 1986. Endfeet of retinal glial cells have higher densities of ion channels that mediated $\mathrm{K}^{+}$ buffering. Nature 324:466-468.

Castillo J, Daval os A, Noya M. 1997. Progression of ischaemic stroke and excitotoxic amino acids. Lancet 348:79-83.

Francke $M$, Pannicke $T$, Biedermann $B$, Faude $F$, Wiedemann $P$, Reichenbach A, Reichelt W. 1997. Loss of inwardly rectifying potassium currents by human retinal glial cells in diseases of the eye. Glia 20:210-218.

GassJ DM . 1997. Stereoscopic atlas of macular diseases: diagnosis and treatment. St. Louis, MO: Mosby. 1061 p.

Hille B. 1992. I onic channels of excitable membranes. Sunderland, MA: Sinnauer. $607 \mathrm{p}$.

I shii M, HorioY, Tada Y, Hibino H, InanobeA, I to M, Yamada M, Gotow T, U chiyama Y, Kurachi Y. 1997. Expression and clustered distribution of an inwardly rectifying potassium channel, $K_{A B}-2 / K_{i r} 4.1$, on mammalian retinal Müller cell membrane: their regulation by insulin and laminin signals. J Neurosci 17:7725-7735.

Karwoski CJ , Xu X, Yu H. 1996. Current-source density analysis of the electroretinogram of the frog: methodological issues and origin of components. J Opt SocAm [A] 13:549-556. 
Kusaka S, Puro DG. 1997. Intracellular ATP activates inwardly rectifying $\mathrm{K}^{+}$channels in human and monkey retinal Müller (glial) cells. J Physiol (Lond) 500:593-604.

Kusaka S, Dabin I, Barnstable CJ , Puro DG. 1996. cGMP-mediated effects on the physiology of bovine and human retinal Müller (glial) cells. J Physiol (Lond) 497:813-824.

Kusaka S, Kapousta-Bruneau N, Green DG, Puro DG. 1998. Seruminduced changes in the physiology of mammalian retinal glial cells: role of Iysophosphatidic acid. J Physiol (Lond) 506:445-458.

Lehre KP, Davanger S, Danbolt NC. 1997. Localization of the glutamate transport protein GLAST in rat retina. Brain Res 744:129137.

Newman EA. 1985. Voltage-dependent calcium and potassium channels in retinal glial cells. Nature 717:809-811.

Newman EA. 1993. Inward-rectifying potassium channels in retinal glial (Müller) cells. J Neurosci 13:3333-3345.

Newman EA, Reichenbach A. 1996. The Müller cell: a functional element of the retina. Trends Neurosci 19:307-312

Newman EA, Frambach DA, Odette LL. 1984. Control of extracellular potassium levels by retinal glial $\mathrm{K}^{+}$siphoning. Science 225:11741175.

Oakley B, II, Green DG. 1976. Correlation of light-induced changes in retinal extracellular potassium concentration with c-wave of the electroretinogram. J Neurophysiol 39:1117-1133.
Puro DG, Stuenkel EL. 1995. Thrombin-induced inhibition of potassium currents in human retinal glial (Müller) cells. J Physiol (Lond) 485:337-348.

Puro DG, Hwang J -J , Kwon O-J , Chin H. 1996. Characterization of an L-type calcium channel expressed by human retinal Müller (glial) cells. Mol Brain Res 37:41-48.

Puro DG, Yuan J P, Sucher NJ . 1996. Activation of NMDA receptorchannels in human retinal Müller glial cells inhibits inwardrectifying potassium currents. Vis Neurosci 13:319-326.

Rauen T, Rothstein J D, Wässle H. 1996. Differential expression of three glutamate transporter subtypes in the rat retina. Cell Tissue Res 286:325-336.

Rauen T, Taylor WR, Kuhlbrodt K, Wiessner M. 1998. High-affinity glutamate transporters in the rat retina: a major role of the glial glutamate transporter GLAST-1 in transmitter clearance. Cell Tissue Res 291:19-31.

Ripps H, Witkovsky P. 1985. Neuron-glia interaction in the brain and retina. Prog Retinal Res 5:181-220.

Sarantis M, Ballerini L, Miller B, Silver RA, Edwads M, Attwell D. 1993. Glutamate uptake from the synaptic cleft does not shape the decay of the non-NMDA component of the synaptic current. Neuron 11:541-549.

Schwartz EA. 1993. L-Glutamate conditionally modulates the $\mathrm{K}^{+}$ current of Müller glial cells. Neuron 10:1141-1149. 